\title{
EFEK BIOLOGI DARI MIKORIZA VESIKULAR ARBUSKULAR UNTUK MENINGKATKAN PERTUMBUHAN TANAMAN DAN STABILITAS AGREGAT TANAH
}

\section{BIOLOGICAL EFFECTS OF VESICULAR-ARBUSCULAR MYCHORRHIZAE TO IMPROVE PLANT GROWTH AND SOIL AGGREGATE STABILITY}

\author{
E. Hanggari Sittadewi ${ }^{1}$ \\ 1 Pusat Teknologi Reduksi Risiko Bencana - TPSA - BPPT \\ Gedung BPPT Lantai 12, JI. M. H. Thamrin No. 8, Jakarta Pusat 10340 \\ e-mail: sittadewi57@gmail.com
}

\begin{abstract}
Vesicular arbuscular mychorrizae (MVA) is a key player in triggering vegetation development and soil reinforcement due to its potential to increase plant growth and soil aggregate stability. In terms of enhancing plant growth, the vesicular-arbuscular mycorrhizae provides greater and more efficient access through the fungal hyphae for nutrient absorption and delivery to the plant. From the side of soil mechanical, the potential of vesicular-arbuscular mycorrhizae is to increase the soil aggregate stability. These potentials, in their application can contribute to soil and slope stability. The characteristics and biological effects of vascular-arbuscular mycorrhizae to increase plant growth and soil aggregate stability in the correlation to slope stability will be discussed in this paper.
\end{abstract}

Keywords : Vesicular arbuscular mychorrizae, plant growth, soil aggregate stability, slope stability.

\begin{abstract}
ABSTRAK
Mikoriza vesikular arbuskular (MVA) menjadi pemain kunci dalam memicu perkembangan vegetasi dan penguat tanah karena potensinya dalam meningkatkan pertumbuhan tanaman dan stabilitas agregat tanah. Dalam hal meningkatkan pertumbuhan tanaman, mikoriza vesikular arbuskular menyediakan akses yang lebih besar dan lebih efisien melalui hifa jamur untuk penyerapan nutrisi dan mengirimkan ke tanaman. Dari sisi mekanis tanah, potensi mikoriza vesikular arbuskular adalah meningkatkan stabilitas agregat tanah. Potensi tersebut dalam aplikasinya dapat berkontribusi terhadap stabilitas tanah dan lereng. Karakteristik dan efek biologis mikoriza vasikular arbuskular untuk meningkatkan pertumbuhan tanaman dan kestabilan agregasi tanah dalam korelasinya terhadap stabilitas lereng akan didiskusikan pada paper ini.
\end{abstract}

Keywords : Mikoriza vesikular arbuskular, pertumbuhan tanaman, kestabilan agregasi tanah, kestabilan lereng. 


\section{PENDAHULUAN}

\subsection{Latar Belakang}

Kestabilan agregat tanah pada lereng dapat berpengaruh positif terhadap kestabilan lereng. Selain itu, keberadaan vegetasi juga berperan dalam mempertahankan kestabilan lereng. Pengaruh vegetasi terhadap kestabilan lereng tersebut antara lain karena penetrasi akarnya yang bertindak sebagai penguat ke dalam tanah dan juga karena fungsi vegetasi dalam manajemen air melalui proses evapotranspirasi dan intersepsi. Monteleone dan Sabatino (2014) mengatakan bahwa stabilisasi tanah secara vertikal adalah karena sistem perakaran tanaman dan juga efek drainasi yang terjadi melalui proses absorbsi air dan transpirasi. Sistem perakaran juga dapat menambah daya kohesi sehingga akan menghambat terjadinya gerakan tanah. Dengan adanya peran tanaman/ vegetasi yang besar terhadap stabilisasi lereng, maka tanaman harus tumbuh dan bertahan hidup. Fungi yang bersimbiosis, seperti mikoriza vesikular arbuskular, merupakan komponen kunci dari populasi jamur yang mempengaruhi pertumbuhan tanaman dan produktivitas tanah (Johansson et al., 2004). Graf et al. (2019) mengatakan bahwa fungi mikoriza secara signifikan dan positif berkontribusi pada pertumbuhan dan kelangsungan hidup tanaman yang berkorelasi dapat menjaga stabilitas tanah/ lereng.

Fungi mikoriza vesicular arbuscular merupakan mikroorganisma tanah yang terdapat hampir di segala jenis tanah. Fungi mikoriza ini pada umumnya dapat ditemukan pada species tanaman tingkat tinggi yang tumbuh pada berbagai tipe habitat dan iklim. Adapun penyebarannya bervariasi menurut iklim, lingkungan dan tipe penggunaan lahan (Setiadi, 2001). Mikoriza terbentuk karena adanya symbiosis mutualisme antara cendawan atau fungi dengan sistem perakaran tumbuhan dan keduanya saling memberikan keuntungan. Penampang dari formasi simbiose mikoriza vesikular arbuskular diperlihatkan pada Gambar1. Mikoriza bekerja dengan cara menginfeksi sistem perakaran tanaman inang dalam memproduksi jaringan hifa eksternal yang tumbuh secara ekspansif dan menembus lapisan sub soil tanah, sehingga dapat meningkatkan kapasitas akar dalam penyerapan hara dan air. Menurut Dahono (2015), mikoriza juga dapat hidup bebas di rizofer. Mikoriza mempunyai peranan yang cukup penting dalam hal konservasi siklus nutrisi, membantu memperbaiki struktur tanah, transportasi karbon di sistem perakaran, mengatasi degradasi kesuburan tanah serta melindungi tanaman dari penyakit. Selanjutnya dikatakan oleh Leake et al. (2004) bahwa sistem miselium ekstensif (bagian vegetatif jamur) secara efektif menjelajahi substrat tanah untuk memperoleh unsur hara anorganik tanah termasuk unsur hara makro $\mathrm{N}, \mathrm{P}$ dan $\mathrm{K}$ dan beberapa unsur hara mikro, $\mathrm{Cu}, \mathrm{Fe}$ dan $\mathrm{Zn}$, dengan sebagian kapasitasnya untuk mendapatkan nitrogen dan fosfor organik. Unsur hara yang diperolehnya tidak hanya penting untuk pengembangan mikoriza itu sendiri tetapi juga sebagian dipindahkan ke tanaman inang. Selain perannya yang besar dalam meningkatkan pertumbuhan tanaman, mikoriza vesicular arbuscular berpotensi meningkatkan kestabilan agregasi tanah.

Dengan melihat karakteristik dan potensi dari mikoriza vesikular arbuskular tersebut, sangat relevan untuk diaplikasikan pada pengembangan vegetasi di lereng, bahkan dalam kondisi yang kurang baik sekalipun.

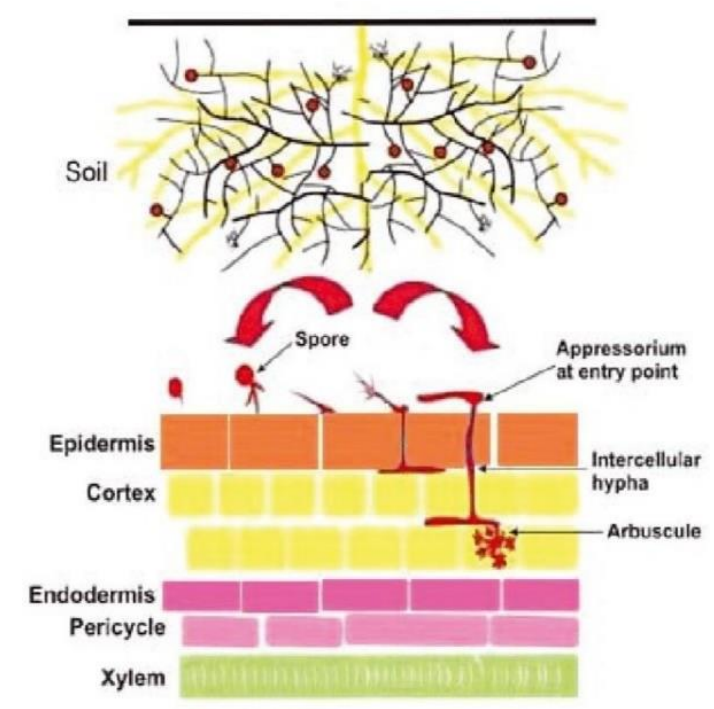

Gambar 1. Skema Urutan Terjadinya Symbiosis Dari Mikoriza Vesikular Arbuskular, Ditampilkan Secara Skematik (Sumber : Garg, $\mathrm{N}$ dan S.Chandel, 2010).

\subsection{Tujuan Penelitian}

Dalam studi ini akan dilakukan analisa dan pembahasan baik dari literatur maupun dari penelitian yang sudah ada tentang potensi mikoriza vesicular arbuscular dalam meningkatkan pertumbuhan dan pertahanan hidup tanaman serta memantabkan kestabilan agregat tanah. Diharapkan dari hasil studi ini dapat dijadikan referensi dalam penelitian selanjutnya terutama dalam implikasinya untuk stabilitas lereng. 


\section{BAHAN DAN METODE}

\subsection{Bahan Penelitian}

Penelitian ini dilakukan berdasarkan studi literatur yang berasal dari penelusuran jurnal ilmiah internasional, jurnal ilmiah nasional, artikel, buku, terkait karakteristik, peran dan potensi dari mikoriza vesikular arbuskular khususnya dalam meningkatkan pertumbuhan dan pertahanan hidup tanaman serta kestabilan agregasi tanah dan stabilitas lereng. Hasil - hasil penelitian yang mutakhir terkait pokok bahasan yang digali dari jurnal internasional dan nasional dijadikan bahan diskusi dalam tulisan ini.

\subsection{Metode Penelitian}

Kajian tentang efek biologis Mikoriza Vesikular Arbuskular (MVA) untuk meningkatkan pertumbuhan dan pertahanan hidup tanaman serta stabilitas agregasi tanah dan stabilitas lereng dilakukan dengan metode sebagai berikut :

- Melakukan studi pustaka atau literatur baik tentang informasi, data maupun penelitian sebelumnya melalui penelusuran jurnal, buku atau website terkait pokok bahasan.

- Mendeskripsikan secara umum tentang karakteristik mikoriza vesikular arbuskular

- Mendeskripsikan efek biologis mikoriza vesikular arbuskular untuk pertumbuhan dan pertahanan tanaman.

- Efek mikoriza vesikular arbuskular terhadap kestabilan agregat tanah

- Implikasi pemanfaatan mikoriza vasikular arbuscular untuk stabilitas lereng

- Menganalisis dan menyimpulkan hasil deskripsi secara keseluruhan tentang efek biologis mikoriza vesicular arbuskular pada pertumbuhan dan pertahanan hidup tanaman serta kestabilan agregasi tanah dan stabilitas lereng.

\section{HASIL DAN PEMBAHASAN}

\subsection{Karakteristik Dan Penyebaran Mikoriza Vesicular Arbuskular (MVA)}

Mikoriza vesikular arbuskular adalah salah satu kelompok fungi yang hidup di dalam tanah, termasuk golongan endomikoriza yang mempunyai struktur hifa yang disebut arbuskula. Arbuskula berperan sebagai tempat kontak dan transfer hara mineral antara fungi dan tanaman inangnya pada jaringan korteks akar. Mikoriza vesikular arbuskular pada umumnya membentuk resting spore dalam tanah, baik secara tunggal ataupun dalam bentuk sporokarp sebelum berinteraksi dengan akar suatu inang. Spora mikoriza dapat terbentuk pada ujung hifa eksternal, ukuran spora bervariasi tergantung pada jenisnya. Bentuk spora, jumlah, dan jenis yang ditemukan pada masing-masing sampel tanah yang berbeda juga bervariasi. Keadaan ini menunjukkan adanya keanekaragaman mikoriza yang terdapat pada masing-masing hamparan tanah. Perkembangan mikoriza ini diawali sejak berada di tanah dalam bentuk spora hingga dapat menginfeksi akar tanaman. Mikoriza tidak hanya berkembang pada tanah yang berdrainase baik saja, pada lahan yang tergenang seperti pada padi sawah mikoriza juga mampu hidup, pada lingkungan yang miskin hara atau pun lingkungan yang telah tercemar limbah berbahaya sekalipun, mikoriza mampu memperlihatkan eksistensinya. (Nurhidayati,dkk, 2010). Mikoriza merupakan salah satu mikroorganisme tanah yang bersifat obligat. Fungi ini memiliki kemampauan bersimbiosis secara mutualistik dengan $80 \%$ species tanaman (Berruti et al., 2016).

Fungi mikoriza vesikular arbuskular merupakan mikroorganisme tanah yang terdapat hampir di segala jenis tanah. Fungi mikoriza ini pada umumnya dapat ditemukan pada spesies tanaman tingkat tinggi yang tumbuh pada berbagai tipe habitat dan iklim. Adapun penyebarannya bervariasi menurut iklim, lingkungan dan tipe penggunaan lahan (Setiadi, 2001). Hubungan antara jumlah spora dengan pertumbuhan tanaman menunjukkan hubungan positif dalam hal menyerap unsur hara. Hubungan yang positif tersebut cukup memberikan indikasi yang jelas tentang peluang penggunaan fungi mikoriza untuk meningkatkan pertumbuhan tanaman, membantu memperbaiki dan meningkatkan sifat-sifat struktur agregat tanah. Adapun beberapa fungsi dari mikoriza vesicular arbuscular pada ecosystem darat diperlihatkan pada Gambar 2 (Garg dan Shikha, 2010).

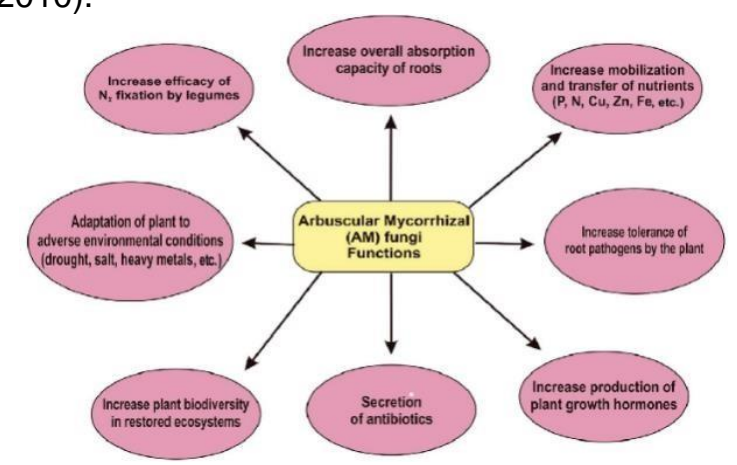

Gambar 2. Beberapa Fungsi Symbiosis Dari Mikoriza Vesikular Arbuskular Pada

Ecosystem Darat (Sumber : Garg, N dan S. Chandel (2010). 


\subsection{Efek Biologis Mikoriza Vesicular Arbuskular (MVA) Terhadap Peningkatkan Pertumbuhan Dan Pertahanan Hidup Tanaman}

Mikoriza vesikular arbuskular mempunyai efek positif terhadap pertumbuhan tanaman bahkan pada tanah-tanah dengan kondisi yang kurang menguntungkan. Isolat cendawan mikoriza yang berada secara alami di area yang tercemar logam berat lebih toleran daripada isolat dari area yang tidak tercemar. Dalam hal ini mikoriza mengifeksi akar tanaman di lingkungan yang tertekan logam berat secara efisien (Burreti et al., 2016). Mikoriza menginfeksi sistem perakaran tanaman inang dalam memproduksi jaringan hifa eksternal yang tumbuh secara ekspansif dan menembus lapisan sub soil tanah, sehingga dapat meningkatkan kapasitas akar dalam penyerapan hara dan air. Semakin banyak tingkat infeksi akar yang terjadi, memungkinkan jaringan hifa eksternal yang dibentuk semakin panjang dan menjadikan akar mampu menyerap fosfat lebih cepat dan lebih banyak. Aher (2004), mengatakan bahwa mikoriza mempunyai peranan yang cukup besar dalam meningkatkan produktivitas tanaman di lahan marginal maupun dalam menjaga keseimbangan lingkungan. Dalam hubungan bersimbiosis dengan tanaman, mikoriza akan mendapatkan keuntungan dari akar tanaman berupa nutrisi karbohidrat dan zat tumbuh lainnya untuk keperluan hidupnya. Beberapa hasil penelitian menunjukkan bahwa bibit tanaman yang bermikoriza tumbuh lebih cepat, tahan kekeringan, tumbuh lebih baik pada tanah miskin hara dan ber - $\mathrm{pH}$ rendah.

Menurut Harumi (2006) manfaat yang dapat diperoleh dari adanya asosiasi mikoriza yaitu meningkatkan penyerapan unsur hara, meningkatkan ketahanan terhadap kekeringan dan ketahanan terhadap serangan patogen. Hal ini juga sesuai dengan hasil penelitian Graf et al. (2019), tentang peranan mikoriza terhadap peningkatkan pertumbuhan dan pertahanan hidup tanaman Laccaria, sp. Terdapat perbedaan secara signifikan antara tanaman yang diinokulasi dengan mikoriza dibanding perlakuan kontrol (tidak diinokulasi dengan mikoriza). Selanjutnya dikatakan bahwa rentang waktu terjadinya efek positif dari mikoriza tergantung dari species jamur mikoriza yang digunakan, meskipun jenis tanaman yang diinokulasi dari satu genus bahkan berasal dari species yang sama. Sedangkan menurut Tahat dan Sijam (2012) dalam hubungan simbiose mutualisme antara tanaman dan mikoriza ditentukan oleh tipe cendawan mikoriza dan kondisi lingkungan. Peningkatan pertumbuhan tanaman bermikoriza lebih nyata pada tanah dengan tingkat kesuburan rendah atau moderat. Selain meningkatkan $\mathrm{P}$, penyerapan $\mathrm{Zn}, \mathrm{Cu}$, S dan unsur-unsur lainnya juga meningkat. Peningkatan senyawa phosphat ini karena cendawan mikoriza melepaskan berbagai asam organik yang dapat meningkatkan kelarutan senyawa fosfat tak larut yang ada di tanah (Jamal et al, 2018). Bentuk fosfor yang tidak tersedia diubah menjadi bentuk yang tersedia sebagai hasil dari asam organik yang diproduksi oleh cendawan (Bolduc dan Hijri, 2010)

\subsection{Efek Mikoriza Vesikular Arbuskular Terhadap Kestabilan Agregat Tanah (Soil Aggregate Stability)}

Tanah mengendalikan pertumbuhan akar, resapan air, aerasi dan siklus hara karena itu tanah merupakan komponen penting untuk kesehatan tanaman. Untuk melakukan fungsi fungsi tersebut, komponen biologi tanah beserta sifat fisika dan kimia tanah perlu berinteraksi secara ideal. Salah satu cara yang dapat memperbaiki sifat fisika tanah secara berkelanjutan adalah pemanfaatan mikoriza vesicular arbuskular. Asosiasi mikoriza vesicular arbuskular diakui sebagai pemicu penting dalam agregasi tanah melalui aksi dari akar individu, miselia dan protein tidak larut yang terkandung dalam mikoriza, menyerupai lem dan bersifat hidrofobikglomalin. Nichols (2008) juga mengatakan bahwa hifa dari mikoriza dan biomolekul, seperti glomalin sebagai komponen hifa, penting untuk proses biologi tanah karena interaksi mereka dengan tanaman, tanah, dan mikroba tanah. Hal ini berhubungan dengan kestabilan agregat tanah. Agregasi tanah merupakan properti tanah yang mempengaruhi berbagai proses fisik dan kimiawi dalam ekosistem tanah yang di mediasi oleh organisme tanah. Dari hasil penelitiannya, Peng et al. (2013) menyimpulkan bahwa jaringan hifa inokulasi mikoriza vesicular arbuskular dapat meningkatkan pembentukan dan stabilitas agregat tanah dalam kondisi sangat mirip dengan yang terjadi di alam. Hal ini diperkuat dengan hasil penelitian Graf et al. 2019, bahwa dengan inokulasi mikoriza pada species Betula pendula didapatkan potensi agregasi tanah yg lebih tinggi jika dibandingkan dengan tanaman kontrol (tanpa inokulasi mikoriza). Selanjutnya Graf dan Frei (2013) juga membuktikan tentang efek mikoriza vesikular arbuskular terhadap system perakaran inang Alnus incana serta stabilitas 
agregat tanah. Dikatakan bahwa dengan model regresi linier sederhana menunjukkan pengaruh positif yang signifikan antara panjang akar per volume tanah terhadap stabilitas agregat tanah, dibandingkan dengan tanaman kontrol yang tidak diinokulasi dengan mikoriza. Mikoriza menghasilkan akar yang lebih banyak pada Alnus incana secara signifikan, sebagai akibatnya, stabilitas agregat tanah lebih tinggi. Hal ini diperkuat dengan pendapat Rillig dan Mummey (2006) tentang mikoriza vesicular arbuskular yang berperan dalam meningkatkan stabilitas agregasi tanah. Sementara Mardhiah et al. (2014) mengatakan bahwa hal tersebut dapat terjadi melalui hifa ekstraradikal yang diperpanjang di rhizosfer dengan merangsang pertumbuhan akar.

\subsection{Implikasi Pemanfaatan Mikoriza Vasikular Arbuscular Untuk Stabilisasi Lereng}

Efek mikoriza vasicular arbuscular terhadap perkembangan dan pertahanan hidup tanaman serta stabilitas agregasi tanah berkorelasi dan berkontribusi positif pada kekuatan tanah pada lereng. Pada kondisi lereng yang curam dan rentan terhadap erosi, aplikasi mikoriza vesikular arbuskular akan tepat untuk mengatasi periode yang diatur oleh faktor pembatas pertumbuhan, sesuai dengan jenis tanaman. Dari sudut pandang mekanis tanah, stabilitas agregat tanah cocok untuk memperkirakan efek gabungan tanaman dan mikoriza sehubungan dengan kontribusinya terhadap stabilitas tanah dan lereng di lapisan dekat permukaan. Dalam kaitannya dengan hal ini, Mardhiah et al. (2016) meneliti tentang peran jamur mikoriza vesikular arbuskular dalam menahan erosi tanah aliran permukaan. Dari hasil penelitiannya dilaporkan bahwa berkurangnya atau hilangnya tanah dapat dijelaskan dengan efek gabungan dari akar dan hifa ekstraradikal mikoriza vasicular arbuscular dan efek unik panjang hifa mikoriza vasicular arbuscular yang secara signifikan mengurangi berkurangnya atau hilangnya tanah. Dari hasil ini dapat diartikan bahwa pemanfaatan mikoriza vesikular arbuskular dapat diimplikasikan untuk mengatasi erosi pada lereng dan kestabilan lereng.

\section{KESIMPULAN}

Efek menguntungkan dari Mikoriza Vesikular Arbuskular (MVA) terhadap peningkatan pertumbuhan dan pertahanan kehidupan tanaman serta kestabilan agregat tanah dapat dimanfaatkan dan dianjurkan dalam aplikasinya di lapangan sebagai langkah penting untuk diintegrasikan ke dalam konsep manajemen dan mitigasi ketidakstabilan lereng.

\section{PERSANTUNAN}

Ucapan terima kasih kami sampaikan kepada Direktur Pusat Teknologi Reduksi Risiko Bencana (PTRRB) - BPPT sehingga makalah ini dapat diterbitkan di Jurnal ALAMI. Semoga makalah ini dapat memberikan kontribusi pada konsep manajemen dan mitigasi ketidakstabilan lereng.

\section{DAFTAR PUSTAKA}

Aher KL. 2004. Soil Biology-Nothing But Normal and Natural. www.bio-organics.com

Berruti, A., E.Lumini., R. Balestrini., V. Bianciotto. 2016. Arbuscular Mycorrhizal Fungi as Natural Biofertilizers: Let's Benefit from Past Successes. Front Microbiol. 6:1559.

Bolduc, A. R and M. Hijri. 2010. The Use of Mycorrhizae to Enhance Phosphorus : A Way Out the Phosphorus Crisis. J Biofertil Biopestici, 2 : 1-5.

Dahono. 2015. Fungi Mikoriza Arbuskula (FMA) Untuk Tanaman Perkebunan. http://kepri.litbang.pertanian.go.id/new/index .php/infotek/785-fungi-mikoriza-arbuskulafma-utuk-tanaman-perkebunan

Graf, F., A.Bast., H.Gartner and A.Yildic. 2019. Effects of Mycorrhizal Fungi on Slope Stabilisation Functions of Plants. Springer International Publishing AG, part of Springer Nature 2019 W. Wu (ed.), Recent Advances in Geotechnical Research, Springer Series in Geomechanics and Geoengineering, https://doi.org/10.1007/978-3-319-8967176

Graf, F and M. Frei . 2013. Soil aggregate stability related to soil density, root length and mycorrhiza using site- specific Alnus incana and Melanogaster variegatus s.l. Ecol. Eng. Vol. 57. August page $314-$ 323. 2013.

Garg, N and S. Chandel. 2010. Arbuscular mycorrhizal networks: process and functions. A review. Department of Botany, Panjab University, Chandigarh - 160014, India

Harumi N. 2006. Pengujian Efektivitas Inokulum Cendawan Mikoriza Arbuskar (CMA) dengan Media Tanam dan Tanaman Inang berbeda pada Rumput. 
Johansson J.F., L.R. Paul., R.D. Finlay. 2004. Microbial interactions in the mycorrhizosphere and their significance for sustainable agriculture FEMS Microbiol. Ecol. 48, 1-12.

Jamal, A., A. Khan., M. Sharif., H.Jamal. 2018. Application of Different Organic Acids on Phosphorus Solubility from Rock Phosphate. Journal of Horticulture and Plant Research. 2: 43-48.

Leake J., D. Johnson., D. Donnely ., G.Muckle., L. Boddy., D. Read. 2004. Networks of power and influence: the role of mycorrhizal mycelium in controlling plant communities and agroecosystem functioning, Can. J. Bot. $82,1016-1045$.

Monteleone, S., M. Sabatino. 2014. Hydrogeological hazards and weather events: triggering and evolution of shallow landslides. International Soil and Water Conservation Research 2(2) : 23-29

Mardhiah, U., T. Caruso ., A. Gurnel ., M.C. Rillig. 2016. Arbuscular mycorrhizal fungal hyphae reduce soil erosion by surface water flow in a greenhouse experiment. Applied Ecology. Vol 99 page $137-140.2016$

Mardhiah, U., T. Caruso ., A. Gurnell ., M.C. Rillig. 2014. Just a matter of time: Fungi and roots significantly and rapidly aggregate soil over four decades along the Tagliamento River, NE Italy. Soil Biology and Biochemistry 75, 133-142.

Nichols, K. A. 2008. Indirect contribution of AM Fungi and soil aggregation to plant growth and protection. Mycorrhizae : Sustainable Agriculture and Forestry. p. 177- 194,

Peng, S.,T.Guo., G. Liu. 2013. The Effects of arbuscular michhoryzal hyphal networks on soil aggregations of purple soil in southwest China. Soil Biology and Biochemistry. Vol.57. Feb 2013. Pages $411-417$.

Rillig, M.C., D.L. Mummey, 2006. Mycorrhizas and soil structure. New Phytologist 171, $41-$ 53.

Setiadi Y. 2001 "Pemanfaatan Mikroorganisme Dalam Kehutanan" Pusat Antar Universitas Bioteknologi, IPB.

Tahat, M. M and K. Sijam. 2012. Mycorrhizal Fungi and Abiotic Environmental Conditions Relationship. Research Journal of Environmental Sciences, 6: 125-133. 